\title{
BRAVA GENTE BRASILEIRA PEQUENO ENSAIO SOBRE SOCIEDADE E ESTADO POR OCASIÃO DO V CENTENÁRIO
}

José Henrique Santos*

SINTESB - Este ensaio discorre sobre o processo de formaçăo histórica da identidade do povo brasileiro, considerando as diferenças étnicas, culturais e econômicas, conciliadas no imaginário social como resposta à pergunta: quem somos nós? O texto apresenta uma critica contundente às mazelas socioeconômicas existentes no Brasil, que se configuram como a principal dificuldade para a implantação de um Bstado ético.

PALAVRAS-CHAVB - Brasil. Formação histórica. Identidade. Cultura. Ética.
ABSTRACT - This essay focuses on the process of the historical construction of the identity of Brazilian people, by taking into account the ethnic, cultural, and economic differences, reconciled in the social imaginary so as to address the question: who are we? The text presents an in-depth critique of the socialeconomic pathologies in Brazil, insofar as they prove to be the main hindrance to the establishment of an ethical State.

KEY WORDS - Brazil. Historical construction. Identity. Culture. Ethics.

A meus filhos Sérgio e Eduardo e a todos os jovens que lutam por um Brasil mais justo.

A feição do escrivão da frota que aportou ao Brasil há 500 anos, não vos dareí conta da marinhagem e singraduras do caminho, porque o não saberei fazer, e se, na época, deviam ter os pilotos esse cuidado, hoje cabe aos historiadores reconstruir o percurso até o presente, para que não se perca a memória dos feitos passados e se possam unir numa só história as duas pontas de nossa vida.

Nesta exposição tratarei dos seguintes tópicos: (1) Passado e presente; (2) 0 povo brasileiro ou a dificuldade de dizer Nós; (3) A mäo invisível; (4) A crise do estado ético; (5) Epílogo.

\section{Passado e presente}

$\mathrm{O}$ ontem e o hoje se pertencem como o modelo original e seu reflexo; mas o começo é o não-verdadeiro, pois lhe falta produzir os desdobramentos de sua

* Professor Titular da Universidade Federal de Minas Gerais - UFMG; membro da Academia Mineira de Letras. 
própria efetividade e percorrer a distância que o separa de si mesmo, à qual damos o nome de realidade histórica. Esta não pode ser medida apenas pelo tempo transcorrido, porque o tempo nada significa sem os acontecimentos que 0 animam. A medida do tempo é apenas uma abstração cômoda. O presente contém o que foi e era, mas de modo desenvolvido, porque atualiza e suprassume o que havia de possibilidade nos momentos anteriores.

Nenhuma possibilidade pode tomar-se atual sem sofrer a metamorfose que The impöem as novas formas de vida. Considerada a partir do presente, a realidade histónica sofre uma transformação inusitada, parecendo coagular-se numa espécie de atualidade pura, que anula a sucessão dos eventos para fazê-la ressurgir na coexistência. O tempo se manifesta entäo sob a regra do espaço; e o que outrora se ordenava na série do um depois do outro, do antes e do depois, pode agora tornar-se simultâneo, um ao lado do outro. A histónia dos efeitos não é a história das causas. Na atualidade, a Reforma e a Revolução Francesa perdem a medida de tempo que as separa, cerca de dois séculos e meio, e, enquanto conseqüência de si mesmas, coexistem lado a lado no mesmo espaço, como aquisição permanente da modernidade. A primeira é a fonte viva da liberdade interior, ao passo que a segunda se mantém como fundamento das liberdades politicas. Ambas se completam, para formar uma realidade mais rica do que se existissem isoladamente. O resultado contém sempre mais do que o ponto de partida.

O princípio da história atuante deixa de ser uma vis a tergo, uma força que se exerce por trás do palco, para ocupar a cena. Assim diremos que a história é essencialmente resultado, mas se este não pode ser separado de sua gestação, pode no entanto ser considerado como o mundo no qual uma forma de vida alcança sua última expressão. Esta não é algo acabado, que se possa comparar à conclusão das premissas no silogismo, pois continua aberta a mil possibilidades. Cada momento contém a verdade dos momentos anteriores, assim também o momento atual, mas este não traz em si sua própria verdade, pois sua efetivação depende de um futuro que ainda não aconteceu.

O fenômeno da aceleração da história no mundo contemporâneo, que se mede por unidades de tempo cada vez menores, quase vertiginosas quando comparadas à milenar história egipcia ou chinesa, despertou a atenção de muitos historiadores, que o atribuíram à dinâmica de um mundo dominado pela tecnologia e pelos meios que ela oferece à nossa ação. Todavia, falta considerar o fenômeno em si mesmo; ele ocorre toda vez que trocamos o processo pelo resultado e nos aproximamos do eterno presente em que desde sempre vivemos. A aceleração do tempo histórico adquire tamanha velocidade que o tempo parece desembocar na simultaneidade de todos os eventos vividos pela consciência. Não mais importa onde e quando os fatos tenham acontecido, pois o mundo espiritual já não coincide com a geografia física e com a procedência histórica. Os lugares e os tempos se despem da individualidade que possuiam e ressurgem num sistema de referência no qual as coordenadas, livres do ponto de origem, se estendem por todos os aqui e por todos os agora. Tomam-se universais e, como paradigmas de uma nova ordem, habitam o espírito, onde são movidos pelo prodigioso poder da abstração. No universo espiritual, o centro é infinito e está em toda a parte. Esta topografia, chamou-a Platão de tópos noetós; doravante as idéias são a medida do conhecimento e da ação à qual recorremos na busca da verdade. 
O presente possui um magnetismo poderoso, que atrai para sua órbita tudo o que girava antes em torno de outros eixos; ele constitui, de fato, a única perspectiva possivel para julgar os eventos históricos, uma vez que não podemos saltar por cima de nosso próprio tempo. Se é preciso situar os fatos em sua época, com a devida cautela para se prevenirem os anacronismos e as falsas interpretações, em atenção às regras hermenêuticas mais elementares, nem por isso podemos fingir que não os vemos com nossos próprios olhos. Deste modo, a atualidade funciona como o tribunal do passado que decide o que permanece, submetendo-o ao critério do que é vivo e do que é morto. O "passado-presente" se investe então de uma nova forma de vida; sua reflexão em nosso mundo já não corresponde ao retrato original. Quando este passado se atualiza, o mundo que o viu nascer chegou a seu fim, mas a herança dos feitos memoráveis e dos grandes acontecimentos se torna uma aquisição permanente, um eterno agora, que dá sentido à vida e a sustenta. Forma-se, deste modo, a consciência histónica de um povo, capaz de manter presente a memória de si mesmo. Em seu contínuo fluxo, a realidade histónica oferece-nos o paradoxo típico de toda a origem, o de realizar-se na própria supressão e de viver sempre como um outro, na alteridade de si; esta é sua verdade.

Em vão buscaríamos nos reflexos do presente a fisionomia do passado; o retrato histórico nunca pode corresponder ao que foi, pois quando fixamos o flagrante, uma forma de vida envelheceu e não se deixa rejuvenescer. A imagem já näo corresponde ao original, como acontece com as fotografias muito desfocadas. Para restituir ao retrato um pouco da fidelidade a que aspira a ciência, é preciso interpretar os traços que lograrmos identificar, neles reconhecendo a passagem do tempo; interpretar é reconstruir.

\section{2 povo brasileiro ou a dificuldade de dizer Nós}

Quando colocamos lado a lado as etnias que moldaram nossa história colonial, com sua tradição e ethos diferentes, e, depois, as sucessivas migraçōes de outros povos da mais diversa proveniência, surge o primeiro problema posto pela simultaneidade da sociedade brasileira: como desenhar um perfil comum, guardando as respectivas diferenças? Mário de Andrade percebeu-o bem, pois Macunaíma, herói de nossa gente, é "o herói sem nenhum caráter". Não que possua 0 mau caráter dos insensatos, no qual não se pode confiar. A desconfiança que suscita provém, antes, da imaturidade, típica do caráter em formação, que acolhe sem critério certos vícios como se fossem virtudes, dentre eles a preguiça e a esperteza de querer sempre levar vantagem em tudo. Falta-lhe, antes de mais nada, a unidade que em vão esperariamos da síntese de etnias, tradiçōes e costumes diferentes, de modo que nos pudéssemos reconhecer no retrato comum e dizer: nostra res agitur. Reduzida a sua expressão mais simples, a imperfeição do retrato é a dificuldade de dizer nós. Projetando fazer o retrato do herói-síntese, o livro mal consegue justapor os traços comuns: o homem brasileiro é a oposição sem identidade, vem a ser, a indiferença dos extremos, que mal se relacionam entre si, malgrado séculos de convivência. Percebendo este fato, o autor é compelido a compor um livro em forma de rapsódia, na qual as tradições diferentes se unem apenas na superficie, deixando sulcos profundos entre uma e outra, como se fossem estranhas e não se tocassem. 
Arguto comentarista desta rapsódia brasileira, Cavalcanti Proença observa que "Macunaíma nasce índio-negro, fica depois de olhos azuis quando chega ao planalto, enquanto os irmãos do mesmo sangue, um fica índio e outro negro. $\mathrm{E}$ continuam irmãos. Macunaíma entretanto não adquire alma européia. É branco só na pele e nos hábitos. A alma é uma mistura de tudo".' A histónia do herói, paráfrase de nossa história social, é uma encruzilhada de muitas vias que se perdem e logo se recuperam, como se tentássemos atingir por atalhos o caminho principal, que não parece traçado com muita firmeza. As peripécias desconcertantes da história não possuem um fio condutor, como se lhe faltasse o sentido interior, a unidade que distribui as massas espirituais e lhes fixa lugar e função na construção do todo. A dificuldade de dizer nós decorre deste eterno improviso, espécie de preâmbulo infindável que, passados cinco séculos, teima em protelar a peça principal.

Admiremos a cena de nosso primeiro encontro. O escrivão da frota de Cabral registra-o com simplicidade, após terem as caravelas chegado à costa: "dali avistamos homens que andavam pela praia, obra de sete ou oito..." "Eram pardos, todos nus, sem coisa alguma que lhes cobrisse suas vergonhas..." "Ali não pôde deles haver fala, nem entendimento de proveito, por o mar quebrar na costa". O entendimento há de diferir até que se encontre um porto seguro, no qual, depois de ter lançado âncora, o almirante faz vir a sua presença dois mancebos para os conhecer; em seguida, até que, vencida a apresentação por gestos, se aprendam as línguas e se falem as personagens. Eis que surge a primeira astúcia: "Homem não lhes ousa falar de rijo para não se esquivarem mais; e tudo se passa como eles querem, para os bem amansar". ${ }^{2}$ Estes são os começos. Trata-se agora de compor a história que, séculos depois, acolherá outras personagens, as seguintes vindas da África, as demais, do mundo inteiro. Vista com os olhos de hoje, a dificuldade é a mesma: como integrá-las numa só nação, acolhendo a diferença na identidade? Como dizer nós?

$\mathrm{Na}$ impaciência de chegar ao termo sem percorrer as etapas, o discurso mistificador trata logo de encontrar a conciliação na cena primitiva, sem perceber que só a encontra lá por tê-la posto ele mesmo, saltando por cima de cinco séculos de luta e sofrimento. A primeira consideração idealizada da identidade brasileira sem a mediação dos conflitos diria, pois: "Estávamos aqui, quando nós mesmos chegamos. Somos ao mesmo tempo eu e o outro, nós, mistura de raças e de culturas que alcançamos uma alma comum. Afinal, cinco séculos criam uma solidariedade!" Mas o pressuposto desta identidade abstrata articula a primeira astúcia já no primeiro ato: amansar. $\mathrm{O}$ dicionário Aurélio dirá, então, a seu tempo: é governável "o que pode ser dirigido", o que é "dócil, obediente". ' Outras astúcias virão depois, mais eficazes, aplicadas às outras personagens, para dar-lhes regimento $\mathrm{e}$ obediência. A medida em que nos aproximamos do presente, multiplicam-se as dramatis personae e a trama se toma mais complexa, mas não se alteram os pa-

Cavalcanti Proença, M. Roteiro de Macunaíma. São Paulo: Anhembi, 1955, p. 28.

Para a carta de Pero Vaz de Caminha, utilizei a ediçăo preparada por Jayme Cortesāo, Livros de Portugal, Rio, 1943.

3 Citado por FIORI, José Luís. Os moedeiros falsos. Petrópolis: Vozes, 1997, p. 39. 
péis, apenas se atualizam, pois se trata sempre de submeter, assimilar sem integrar, mantendo uma distância de senhores e servos, de superiores e inferiores, que habitam um universo comum, onde cada qual deve conhecer seu lugar.

Quem é o povo brasileiro? Quem somos nós ? Qual é a situação atual dessa polaridade sem síntese de dominadores e dominados? O Prof. Hélio Jaguaribe apresenta a seu modo a questão dos dois brasis. Do ponto de vista econômico, a teoria das etnias e das culturas que lhes são associadas se transforma no que ele chama de "dualismo básico da sociedade brasileira", que consiste no fato de duas sociedades radicalmente distintas habitarem o mesmo espaço territorial e político. "De um lado - escreve ele - existe uma sociedade modema, que opera em condições semelhantes às de um adiantado país europeu, uma economia industrial que já é a oitava do mundo ocidental. Essa sociedade, entretanto, inclui apenas uma parcela minoritária da população. Coexistindo com ela, no mesmo território e nas mesmas cidades, existe uma sociedade primitiva, que vive, nos campos, de uma pobre agricultura de subsistência e, nas cidades, de um miserável terciário marginal e que contém cerca de $60 \%$ da população total". A observação se completa com os seguintes dados: $50 \%$ da população detêm apenas $13 \%$ de toda a renda, igual à que detém $1 \%$ da população mais rica; dos mais pobres, $25 \%$ ganham menos que 1/4 do salário mínimo. Essas cifras expressam a situação ao final da década passada, mas presume-se que os anos noventa apresentem números ainda mais dramáticos.

A dualidade não encontrou meios eficazes para aproximar os extremos, salvo na retórica dos poderosos. Na verdade, o laço de união dos que dizem nós só se fortalece porque se opōe a eles, os deserdados da terra. A identidade é tanto mais forte quanto maior a diferença; ela é sempre a nossa, nunca a deles. Eles, os excluídos, devem manter-se à distância e viver na mais longínqua periferia, sem ameaçar os domínios fechados onde moram a Lei e a Ordem. A idéia de nação abriga, deste modo, a dor e a separação absolutas; ela se nutre de uma cisão ao mesmo tempo interna e profunda.

Mas não são apenas os vencedores que narram sua história, ainda que possuam os meios de fazê-la prevalecer. Também os oprimidos têm o que contar. A substância ética se investe então da complexidade requerida para transformar-se internamente. A contraposição meramente externa de forças que se mantinham em recíproca diferença adquire agora vida interior, torna-se posta pela consciência, e alcança a tensão que é o preâmbulo necessário da liberdade.

Essa nova vida substancial se expressa na literatura mais recente. Joäo Ubaldo Ribeiro descreve em Viva o Povo Brasileiro o surgimento da consciência oprimida, desde os primórdios da escravidão até o mundo atual. A libertação do povo negro é exposta a partir de seu próprio olhar, em quadros sucessivos, que narram a luta quotidiana das gerações. A representação do mundo ético que daí resulta transfere o discurso do opressor para o oprimido. No lugar do panteão clássico, que Camões faz intervir nos Lusíadas, ao lado do Deus cristão, para proteger a

4Jaguaribe, Hélio. Alternativas do Brasil. 2. ed. Rio de Janeiro: José Olympio, 1989, p. 9-10.

5 Ribeiro, João Ubaldo. Viva o povo brasileiro. 6. ed. Rio de Janeiro: Nova Fronteira, 1984. 
esquadra portuguesa em costas de África e Índia, surge agora o panteão dos deuses do candomblé que, na guerra do Paraguai, deliberam sobre a sorte dos brasileiros, em sua maioria soldados negros fôrros. As Tágides podem ainda habitar o Tejo, mas aqui reina Iemanjá sobre os mares e as águas; ${ }^{6}$ em vez de Marte e Febo, temos agora Xangô e Iansã; os orixás do terreiro expulsam os deuses do Olimpo. A literatura expressa as lutas libertánias recitadas pela boca do povo que as empreende. A visão da história transfere-se da casa-grande para a senzala, e, no final do romance, chega o momento da cultura, na qual o escravo, formado na obediência do servir, se torna educado por si mesmo, ao contrário do senhor, que só é capaz de gozo e fruição.

A ideologia da conciliação, no entanto, coloca-nos diante de outro ardil, talvez mais envolvente do que o primeiro, porque encobre o conflito com o manto da tranqüila convivência familiar. Aqui a explicação se organiza a partir da figura do senhor, que distribui os papéis e zela pelo desempenho dos atores. $O$ ritmo é lento, como convém ao enredo concebido para durar muito tempo. Casa-grande e senzala pode ler-se, com efeito, como um romance de formação, ao estilo do Emilio, tal a força expressiva de suas personagens; e também não lhe fica abaixo como ficção. A "formação da família brasileira sob o regime de economia patriar-

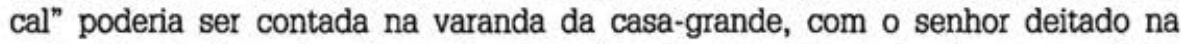
rede, algo modorrento, cismando e imaginando, enquanto se lhe forma o caráter. De fato, escreve Gilberto Freyre no prefácio da primeira edição:

"Nas casas-grandes foi até hoje onde melhor se exprimiu o caráter brasileiro; a nossa continuidade social. No estudo da sua história intima despreza-se tudo o que a história política e militar nos oferece de empolgante por uma quase rotina de vida: mas dentro dessa rotina é que melhor se sente o caráter de um povo."

Os protagonistas se dispõem em torno da intimidade do lar. Primeiro surge o indio, depois o negro; quanto ao branco, nunca está ausente, seja como ator, seja como narrador; é sempre dele que se fala. A maneira dos memorialistas da grande literatura nordestina, trata-se de recuperar o passado para compreender 0 presente, fundindo numa só pessoa, a do autor, o sujeito da narrativa e o escritor, em previsível superposição. Assim se explica a continuidade social do caráter brasileiro, que se formaria como que aprisionado no solitário diálogo consigo mesmo. Nesse monumental solipsismo estaria a raiz de nossa pacífica conciliação; pena que não passe de uma conciliação imaginária. O cogito social, pelo qual uma sociedade diz nós existimos, se investiria então de um ar morno e preguiçoso, confundindo sensualidade com sensibilidade, moleza de costumes com cordialidade, terminando por sublimar a economia real do ciclo de açúcar em sentimentos de afeto e doçura, em vez de prender-se à rude labuta de ganhar a vída.

6 Em alguns poemas de Camões as Tágides representam as mulheres de Lisboa. Entre nós, muitas mulheres negras recebem o nome de Janaína, a rainha do mar, outro apelido de Iemanjá.

7 Freyre, Gilberto. Casa-grande e senzala. 13. ed. Rio de Janeiro: José Olympio 1966. 2 v. v. 1, p. XLIX. Ver a respeito Mota, Carlos Guilherme. Ideologia da cultura brasileira (1933-1974). São Paulo: Ática, 1977 , p. 57. 
Essa economia patriarcal e pré-capitalista passa ao largo dos conflitos econômicos, como se os interesses se acomodassem por ação da natureza, e a formação do caráter dependesse, apenas, da paz familiar, instaurada quando o senhor traz 0 escravo para dentro de casa e o educa na disciplina do serviço doméstico.

A vontade ética que define a vida social é o desejo de obter reconhecimento para a dignidade da pessoa. Não basta agregar o outro à familia; ele será sempre um estranho que mantém a alteridade mesmo dentro da maior proximidade. A separação abissal entre senhor e escravo não envolve apenas o ser, como gostam de dizer os humanistas, mas também o ter, o possuir, a realidade material da existência. É por princípio falsa toda conciliação que não indique o modo de produção, circulação e distribuição dessa espiritualidade material, o dinheiro.

Mas não nos limitemos à ficção histórica, mesmo que possua grande valor literário.' Quando, por uma experiência de pensamento, buscamos compreender a contradição real existente entre dominadores e dominados, e para a luta que travam até mesmo na intimidade das casas, é ainda à literatura histórica que precisamos recorrer se quisermos dar conta daquela permuta dos extremos a que aludíamos, ao tentar inverter o olhar, fazendo-o retornar da senzala para a casagrande. Graças à possibilidade de experimentar o oposto, de pôr-se no lugar de outro, surge a consciência da diferença, não simples diferença, mas identidade na diferença. É neste sentido que a educação muda de lado.

Na obra de Laura de Mello e Souza, O Diabo e a Terra de Santa Cruz, a superstição e 0 atraso ficam com o colonizador branco, que não consegue livrar-se de seus demônios interiores, numa caricatura de religião que a faz descer abaixo das crenças negras. $\mathrm{O}$ diabo se apodera da consciência branca e lhe obscurece 0 juízo; ninguém está livre do mal, e a perdição eterna é o destino dos que não se submetem à ordem estabelecida. ${ }^{\circ} \mathrm{O}$ escravo, ao contrário, se faz livre em si; falta tomar-se livre para si, como sujeito de direitos, reconhecido no mundo da cultura e do trabalho. A cultura do trabalho industrial produzirá, a seu tempo, o novo tipo de homem que aspira a participar da riqueza social e mesmo do poder do Estado.

Após Macunaíma, publicado em 1928, há a revolução de 30 e o desenvolvimento industrial, que adquire densidade a partir dos anos cinqüenta e muda a face do País. A industrialização acelerada produz intensos movimentos migratórios, atraindo parte considerável da população rural para a periferia das grandes cidades, em busca de melhores oportunidades de emprego e educação. Surge um proletariado urbano expressivo, capaz de se organizar e reivindicar direitos trabalhistas e sociais. Isto não se faz sem conflitos e tensões, mas força a reconhecer que a sociedade brasileira adquire nova dinâmica. A fábrica e a empresa tomam possivel que trabalhadores e empregados se reúnam no mesmo local de trabalho. O trabalhador já não encara sozinho o patrão, pois a proximidade física com os companheiros permite se desenvolvam novas formas de consciência. Pela primeira vez, também os outros, eles podem dizer nós: nós queremos, nós reivindicamos.

8 Lembro-me de Oscar Wilde, que escreveu: "The only form of fiction in which real characters do not seem out of place is history"; in: Nothing... except my Genius, compiled by Alastair Rolfe, Penguin Books, 1997, p. 17.

- MELLO E SOUZA, Laura de. O diabo e a Terra de Santa Cruz. São Paulo: Cia das Letras, 1994. 
Passando do discurso à ação, surgem os primeiros movimentos populares em grande escala. No início simples concentrações usadas como massa de manobra, os comícios e as passeatas contribuem para educar consciências e formar dirigentes, mesmo que vigiados pelo poder. Mas liderança e organização se aprendem na prática e se fortalecem no tempo; deste modo, o sentimento difuso de participação vira vontade firme. O queremismo da era Vargas é sobretudo a voz do proletariado urbano a exigir os direitos trabalhistas que outras naçōes haviam conquistado. Ele responde, sem dúvida, antes de tudo, ao chamado do líder carismático, no entanto não poderia fazê-lo se já não estivesse formado na consciência de cada um, existindo como que in nuce, à espera de ocasiảo favorável para atualizar-se.

Hoje a mesma voz encontra eco em outras bocas, como um grito que une a cidade e o campo, aproximando os despossuídos de toda a sorte, desde os semteto e os sem-terra até os sem-emprego da economia global. Eis, pois, o que parece ser o ponto de ruptura com a velha ordem: indo das palavras aos atos, o discurso suplicante de ontem assume a voz de comando e se transforma em princípio de ação; as ocupações de terra e de propriedades sem uso tomam-se a característica dos novíssimos tempos. Todavia essa rebeldia dos que nada possuem está fadada a percorrer muitas vezes o mesmo círculo e recomeçar sem descanso, até que, rompendo a singularidade dos fatos, consiga pôr-se ao abrigo da norma juńdica. Até lá, será apenas o movimento negativo, sem a universalidade da lei, entregue à violência e à destruição de parte a parte. Ora, os que fazem a lei, fazemna mui estreita, na medida de si próprios; parecem mesmo parodiar, a seu modo, o célebre dito de Malthus, segundo o qual os que chegam muito tarde num mundo onde as riquezas já estão distribuídas, não têm direito a reclamar nenhuma parcela de alimento no banquete dos primeiros. A estes sempre cabe perguntar: quando abrirão os olhos?

Lancemos um olhar, por nossa vez, para o imenso contingente dos que acorrem às grandes cidades em busca de trabalho e educação. Expatriados em seu próprio país, esses sem-nada perdem rapidamente o que ainda restava da cultura tradicional que os ligava à terra, centrada na produção de valores de uso, e se adaptam com dificuldade às relações de troca vigorantes na cidade. Aqui um novo ethos é requerido, no qual os valores tradicionais não mais vigoram. Os recémchegados ficam expostos, sem nenhuma defesa, aos costumes desse mundo estranho. As relações pessoais, o sentimento de honra e lealdade, o respeito aos mais velhos, numa palavra, tudo o que permitia dar sentido às idades da vida $e$ sofrer resignadamente as naturais provações, nada disso subsiste, pois agora reinam outros valores.

A cultura de massa da comunicação eletrônica logo cobra seus ingressos. Ela oferece a felicidade do consumo irrestrito, que é impossivel satisfazer pelo trabalho. Os paraísos artificiais vendem a satisfação limitada, mas que precisa ser repetida ad nauseam, pois o desejo é um mau infinito que ressurge tão logo saciado. $\mathrm{A}$ desproporção entre o trabalho e o desejo cresce com o apelo reiterado do consumo, a tal ponto que os ganhos do trabalho, que mal permitem a subsistência, não logram satisfazer às necessidades cultivadas; e por essa via se abre o caminho da marginalidade e da violência. 
Quando, neste drama social, consideramos a sociedade de consumo e a força de sedução que ela exerce nas consciências, apresenta-se outra forma de violência, quase impalpável, mas não menos eficaz, desta vez no tecido interior da vontade. A existência social reflete-se na consciência com o prestígio do desejável, cuja aquisição se torna a finalidade de todos os esforços. A vontade se perde nesse mundo ao mesmo tempo próximo e distante, o mundo dos outros, que the aparece como o céu na terra. $O$ desejo de consumo é a obsessão infinita que expulsa da consciência seu núcleo racional. Deste modo, alienado de si, o mundo interior engole a máquina de pensar do inimigo e julga escapar à dor da separação através da representação fantástica que o desejo alimenta continuamente. A perda de si é o sacrifício oferecido ao altar do consumo.

A manipulação das consciências efetuada pelos meios de comunicação e técnicas de marketing, atendendo aos interesses da riqueza e do poder, toma impossível a percepção correta da realidade. Poucos têm condição de compreender 0 que acontece no mundo econômico e político. Mesmo a imprensa mais lúcida sucumbe freqüentemente aos dogmas do pensamento único, veiculando o noticiário oficial como se refletisse a verdade revelada, sem the acrescentar qualquer reparo crítico. Deste modo, aqueles que, em sua grande maioria, buscam a subsistência num mercado de trabalho cada vez mais competitivo e escasso, mal têm meios de inteirar-se dos fatos do dia-a-dia. Que se dirá de compreender a lógica perversa que os produz e mantém? Demagogos de toda a espécie encontram campo fértil para obter vantagem. A maior perda é fonte do maior ganho. No amplo comércio de nossa vida política, tudo se vende e tudo se compra, pois o poderoso interesse que vem de cima sabe conferir aos atos mais censuráveis a aparência da inocente transação.

A exposição desarmada à cultura de massa não afeta apenas os migrantes. Também os que nasceram e cresceram nas grandes cidades sofrem os efeitos da crise do mundo ético. A educação familiar mais aprimorada está sujeita às injunções das modas e das necessidades fabricadas. Com as comodidades que proporciona, o artificialismo da vida urbana habita sempre a superficie e em nada se aprofunda e demora; a incessante repetição, não a paciência que reflete, é o argumento que the convém. Ele produz um dano irreversivel, que pode chamar-se a perda do estrato expressivo da linguagem. Não encontrando equivalente no código da paidéia eletrônica, a língua tradicional perde a capacidade de expressar os sentimentos e as paixōes da alma. A dificuldade de expressão é a doença infantil dos grupos urbanos. Ora, cada língua possui uma alma peculiar, na qual a cultura se enraiza, conservando seus valores e sutilezas. Nos estratos mais superficiais, bastam poucas expressões, já tipificadas, para realizar as interações padronizadas que o jogo lingüístico permite; é o caso do lazer de massa, a exemplo do futebol e os shows de muito som e pouca música. Nos sistemas de interação mais comple$\mathrm{xos}$, como o do trabalho e o das profissões, o desempenho lingüístico é tanto mais refinado quanto mais especializada (e conseqüentemente mais bem remunerada) a tarefa. Aqui o código lingüístico já funciona por si mesmo como critério seletivo, excluindo a priori os que não o dominam, em niveis tão mais refinados, que chega a parecer uma língua estranha, com sintaxe e vocabulário próprios. Se conside- 
rarmos, além disso, a crescente invasão do inglês nas profissões e mesmo em nossa vida quotidiana, é de ver-se o quanto a competência lingǘstica presumida alia-se ao princípio de desempenho para dificultar aos neófitos o ingresso nos "círculos interiores" das decisões.

A cultura do capital, com sua ética cosmopolita, absorve rapidamente tudo o que se pode e deve saber. Ela profere de mil modos as palavras da riqueza e do poder, que estão em todas as bocas. Mas não diz uma palavra de sabedoria. A cisão entre a cultura tradicional e a cultura popular, entre esta e a cultura de massa, entre a ciência e a superstição, todos esses estranhamentos não mostram sinais de diminuir. Confundimos esperteza com inteligência, mas na realidade falta-nos tudo, sobretudo educação. A perda da linguagem dissimula a mais trágica das contradiçōes, a que existe entre a língua e a fala; aquela tão rica, com sua imponente tradição literária, que n'Os Lusíadas se alevanta em "uma fúria grande e sonorosa", esta tão descuidada, beirando a penúria. Para tornar-se permanente, a conquista da cidadania requer vençamos, antes, a batalha da educação.

\section{A mão invisível}

A contradição entre a grande massa dos deserdados e a élite financeira não dá sinais de que possa ser superada. Pelo contrário, a chamada globalização e 0 novo liberalismo econômico que lhe está associado têm aumentado o fosso entre os extremos, elevando mais ainda a concentração e a má distribuição da riqueza social. A mão invisível de que falava Adam Smith, em vez de harmonizar o todo, só se abre para os happy few, para os poucos que conhecem o "abre-te sézamo" do poder e do lucro. Mesmo o poder do Estado representa uma ordem de interesses econômicos que expulsa do mundo real tudo o que não for útil e produtivo. $\mathrm{Na}$ verdade, o chamado "Estado mínimo" não se despojou apenas do supérfluo e despiciendo, mas da própria soberania, ao dobrar-se ao interesse do capital. 0 poder do Estado tornou-se instrumento da identidade excludente, típica dos novos plutocratas que ascendem à riqueza levados pelo pregão da bolsa de valores. A desigualdade de renda, ensinava Friedrich Hayek em O Caminho da Servidão, de 1944 (e o título do livro não deixa de ser irônico), constitui o motor da prosperidade, pois se a proteção do Estado se estendesse a todos, os improdutivos seriam premiados, sem que a economia recebesse incentivo para crescer. A soberania do Estado, que desde Rousseau se confundia com a vontade geral, restringe-se, pois, a poucos, visto que as reformas fiscais devem incentivar o capital com leis adequadas, em detrimento da massa de assalariados. Deste modo, as decisões políticas hão de estar em mãos seguras. Como dizia com propriedade o brasilianista Skidmore, "os de dentro" excluem, por definição, "os de fora". ${ }^{10}$

$\mathrm{O}$ incentivo ao capital faz com que o Estado brasileiro o desonere de taxas, como também isenta os muito ricos de contribuir na proporção de sua riqueza. A fim de se manter a máquina estatal, o governo recorre cada vez mais aos impostos, diretos ou indiretos, cobrados muito desigualmente do que ainda resta da população economicamente ativa. Do mesmo modo, os juros altos premiam os

10 Skidmore, Thomas. De Getúlio a Castelo. 3. ed. Rio de Janeiro: Paz e Terra, 1975. 
investidores, alienígenas ou não, em prejuízo da indústria e da agricultura nacionais, que se tornam incapazes de competir com os produtos estrangeiros, protegidos por isençōes que o recente acordo internacional proibe modificar.

$\mathrm{Na}$ indústria do lazer, o usuário preenche o tempo ocioso e o dispersa na negatividade; paga para não trabalhar e não ter negócio (nec-otium) que lhe impeça a diversäo. No "crescimento negativo" de nossa economia, no entanto, o operário paga para trabalhar, devendo comprar parte do próprio emprego. Contribui, portanto, a cada mês com um ágio de $20 \%$ a título de redução salarial, sob pena de ser despedido. Do mesmo modo, o servidor público necessita comprar pela segunda vez o benefício há muito adquirido. Num caso e noutro, o que estão a vender e comprar é a própria escassez, a falta de, a ameaça de privação. 0 sistema se alimenta de sua fraqueza constitutiva e como ainda pode comercializar o não-ter, 0 Estado, por sua vez, crê desnecessário intervir para endireitar os caminhos, seja porque the falte sensibilidade para perceber os problemas, ou porque não saiba como resolvê-los. É patente que a sociedade está sendo exaurida; tudo isto é sabido, mas os economistas de profissão demonstrarão com mil e um argumentos que este é o único caminho possível. Não será pois um filósofo, mais afeito a outras especulações, quem o dirá com suficiente energia.

No Estado democrático, cabe à Justiça garantir os direitos do cidadão e legitimar a soberania do povo, transferida ao Estado mediante o sistema representativo. A concentração da riqueza submeteu o poder do Estado às conveniências da economia de mercado, vale dizer, ao interesse privado. A antiga economia política (political economy), que subordinava a economia à política do Estado, tornou-se mera ciência econômica (economics), despida de qualquer preocupação política e social, voltada ao estudo das leis que regulam automaticamente o sistema de produção, troca e consumo de agentes indíviduais. $O$ espaço público foi submetido ao interesse privado, sendo ao mesmo tempo privatizado.

O Estado conivente com esta capitis diminutio denomina-se Estado mínimo ou Estado neutro, pairando acima do mundo real com olímpica indiferença, como o deus dos antigos, que sub luna non curat. A democracia nominal tolerada pelo Estado mínimo perdeu a capacidade de decidir e, nos parlamentos, se entrega a uma discussão estéril e sem fim. Ela se ilude, ao pensar que da discussão nasce a verdade; pois toda opinião é tolerada e mesmo bem recebida, porque sua função é dar aparência de legalidade ao exercício do poder discricionário. As decisões que aqui se impõem são tomadas pelos agentes econômicos, e delas não é possível recorrer, porque se consideram válidas somente as pronunciadas em instância final, nos pregões da bolsa de valores. $O$ veredito é proferido na forma de um juizo incontestável, expresso no valor das açōes, dos leilões e dos investimentos. Neste comércio não existe opção, a não ser aquela que se passa no reino da mera quantidade. A lei básica deste estado privado pertence à psicologia do interesse ou à natureza do mercado, há muito chamada de lei da oferta e da procura. Mas só agora se vislumbra seu formidável poder, capaz de submeter o Estado e transformá-lo em instrumento de finalidades alheias. 
Deste modo se degrada também toda a esfera do político, que é o reino da decisão. Ora, a essência da soberania consiste em poder decidir; conseqüentemente, se ela não o faz, suprime-se a si mesma e se anula. Não é mera coincidência ouvir-se a repetida queixa de que "falta vontade política". No Estado de menor valia, o governo não governa, porque entrega a decisão aos grupos de interesse; administra, mas administra mal, porque, na falta de políticas consistentes, não consegue conciliar a multiplicidade de interesses privados.

Nosso desafio maior está em definir a ética da conduta política. Não basta exigir de deputados e vereadores mais "ética na política", pois, em sua maior parte, devido à própria estrutura do poder político, eles ignoram o que realmente ocorre na esfera das decisōes e freqüentemente desconhecem o que ultrapassa seu proveito pessoal. Sem dúvida, a política pode atender também a grupos de interesse, que não são necessariamente ilegítimos (e nunca deveriam ser). Mas, de qualquer forma, é preciso fazer valer as regras do jogo no domínio das disputas partidárias e definir o que é permitido e o que é interdito. Toda a necessária reforma política há de consistir em estabelecer leis claras e objetivas que regulem a vida pública. A confusão com os interesses que se disfarçam sob justificativas morais só serve para obscurecer os problemas, alimentando uma infindável troca de acusações, na qual todos se põem contra todos. Cada qual pretende ter razão contra o adversário, pois o discurso político tanto é capaz de descobrir quanto de encobrir a verdade. Verdade e falsidade não se restringem a convicções bem assentadas, que podem ser meros preconceitos, mas são fundamentalmente assunto de argumentos, provas e conclusões. Sempre haverá meios de justificar atitudes e interesses pessoais, ainda que imorais, porque a arte retórica não visa à verdade, mas à persuasão.

A percepção que cada indivíduo tem da moralidade ou imoralidade das ações políticas, mesmo que necessánia, é por si mesma insuficiente para impor sejam assumidos novos valores. É preciso ir além da reprovação subjetiva que se limita à experiência do próprio desgosto, e transformar a capacidade de nos indignarmos em meios de ação.

Ao estudar os problemas colocados pela democracia moderna, Chantal Mouffe escreve exemplarmente:

"Nas condições modernas, em que o individuo e o cidadão não coincidem devido à separação entre o privado e o público, é necessária uma reflexão sobre os valores autônomos do político. É precisamente esta a tarefa da filosofia política, que tem de distinguir-se da filosofia moral."

No que diz respeito à verdade, sendo infinita sua busca, o Estado não poderia esperar encontrá-la para só então vir ao mundo. Na origem do Estado só é verdadeira a vontade que se quer livre na universalidade do povo e se faz existir como instituição organizada. A expressão jurídica clássica "dizer o direito" significa ordenar a produção do efeito, isto é, pôr-se a si mesmo na existência. Aqui sempre se presume a legitimidade, seja em função da lei, ou, em sua ausência, em função da racionalidade do próprio direito. Quando se trata de uma instituição

" MOUFFE, Chantal. O regresso do politico. Lisboa: Gradiva,, 1996, p. 152. 
originária como o Estado, a decisão de fazer-se valer deriva, de fato, do poder que a autoridade se confere a si mesma, cuja legitimidade só pode provir da universalidade ética que lhe é inerente. Não fosse o Estado, por definição, "estado da liberdade", seria impossível encontrar para ele qualquer outra legitimação. Ele é a razão tornada livre, e só assim pode a palavra instauradora do direito assumir a autoridade que ela mesmo ordena. O Estado soberano há de ter poder, senão estaria submetido a outro; mas também há de possuir legitimidade, do contrário seria contraditório consigo mesmo. Esta dupla origem, de fato e de direito, permite escapar ao falso dilema de imaginar que, para ser democrático, o Estado não deva possuir poder, e que, tendo poder, não possa ser democrático. Na verdade, o Estado autoritário só satisfaz a uma condição, a de possuir poder, ao passo que o Estado democrático é o único que pode satisfazer a ambas, poder e legitimidade. Por este motivo, ao Estado democrático repugnam o arbítrio, a arrogância e as vaidades pessoais, que enfraquecem e defraudam as leis da liberdade.

Podemos agora retornar à questão da soberania sem confundi-la com autoritarismo. A coerção implícita na leí só pode ser legítima no Estado de direito porque 0 que a justifica é a defesa da liberdade. $O$ que se chama imperium é a faculdade de mandar e ser obedecido; é ao mesmo tempo norma e força, legitimidade e poder.

Logo na primeira linha de sua Teologia Política, Carl Schmitt define a soberania: "é soberano quem decide sobre a situação excepcional" ${ }^{12}$ Não podemos desconhecer as simpatias de Schmitt pelo Estado totalitánio; no Estado democrático, contudo, "quem decide" não é o Führer, mas o próprio povo, que deste modo manifesta sua vontade. Por conseguinte, no poder do Estado, o cidadão encontrase consigo mesmo, com sua liberdade realizada e organizada. Assim, ao introduzir o conceito de Estado em sua Filosofia do Direito, Hegel o define como "a realidade em ato da idéia ética", e três parágrafos adiante, tratando já do direito político interno, como "a realidade em ato da liberdade concreta" ${ }^{13}$ Este é o Estado ético que o neoliberalismo escamoteia. Ele é o reino dos fins, porque é o reino da liberdade realizada. Deste modo, nunca poderia tornar-se meio ou instrumento de vontades alheias; menos ainda poderia servir a interesses particulares sem perder a identidade ética, pois esta não pode deixar de ser universal.

\section{A crise do Estado ético}

Quando se obliteram as distinções entre o público e o privado, toda a ética que legitimaria a função política do Estado fica relegada ao domínio da vontade individual. Como esta pode variar ao infinito, o conflito de interesse se instala no

12 SCHMITT, Carl. Politische Theologie. Berlim, 1985. Edição francesa, Théologie politique (Paris: Gallimard, 1988, p. 15). Para a definiçăo do politico (das Politische), ver, do mesmo autor, $O$ conceito do politico (Petrópolis: Vozes, 1992). Sabe-se que Schmitt colaborou com o partido nazista após a tomada do poder. Todavia dele retemos a crítica sobre as fraquezas da democracia parlamentar, sobretudo da República de Weimar, que perdeu a soberania no esfacelamento dos partidos e na ausência de um projeto político claramente definido. Será que a história ensina alguma coisa? HEGEL, G. W. F. Grundlinien der Philosophie des Rechts. 5. ed. Suhrkamp, 1996, § 257, p. 398; § 260, p. 406. 
exercício do poder e, em vez de apresentar solução para os males que afligem o povo, os que o exercem usam o cargo para aumentar o próprio poder e perpetuarse nele. Nem todos o fazem, é certo, pois a probidade não desapareceu de todo da vida política. Mas que podem os justos contra lobos travestidos de ovelhas?

Sempre se pensou que o Estado digno desse nome devesse defender-se de quaisquer inimigos. Os hinos patrióticos não se cansam de repetir o dilema de independência ou morte. Mas ninguém dá a vida por um pacto, ainda que este se chame contrato social. Não existe heroísmo da abstração. A invasão interna do Estado é insidiosa e suave, e quase não encontra resistência. Ela se protege com muitas razões e chega mesmo a dar-se um ar de respeitabilidade, exigindo a austeridade de hoje para renovar a promessa de amanhä.

Semelhante Estado hipotético mais serve ao lucro do que à justiça. Com sua bênção se fazem e se desfazem os pactos, segundo as necessidades do capital. Mesmo a Constituição não está a salvo das conveniências do momento. A esse Estado do entendimento, que se caracteriza pela satisfação de interesses particulares, devemos opor o Estado da Razão, no qual o costume e a cultura (a eticidade substancial) que 0 animam se eleva à universalidade nomotética, que não provém de nenhum contrato e de nenhum arbítrio. Esta procede de uma decisão que já está historicamente tomada e possui, hoje, a força da tradição. O Estado nomotético é aquele que se põe (thesis) a si mesmo na lei (nómos) e que, por isto, não subordina sua vontade a nenhuma outra. A vontade com a qual se autodetermina é universal e não conhece outro interesse senão o interesse da razão e da liberdade: é a expressão, traduzida em norma, dos valores do povo. ${ }^{14}$ Deste modo, ao se dar existência, o Estado se investe, ao mesmo tempo, da autoridade ética que as leis da liberdade conferem. Não deriva de um pacto hipotético, como propõe Hobbes, que permita aos indivíduos, movidos pelo medo, sair da condição natural para entrar na sociedade civil, ou, de acordo com Locke, pelo desejo de proteger a propriedade. Ao contrário, o Estado fundado na razão possui o poder por autoafirmação e não está condicionado por contratos anteriores à sua existência. A soberania não lhe vem de fora, descansa na própria vontade e constitui o fundamento sobre o qual é possivel construir a liberdade; ela é autarchéia, autarquia que tem o domínio de si.

$\mathrm{O}$ grande historiador das razões de Estado, Friedrich Meinecke, escreve que a força e o costume, isto é, "kratos e ethos fundam juntos o Estado e fazem a história". ${ }^{15}$ Esta fórmula se ajusta bem à concepção histórica do Estado da Razão, oposta ao Estado do entendimento, no qual mergulhou a modernidade.

Nossos tempos pós-maquiavélicos assistiram à decomposição do Estado ético por obra da profunda cisão entre os dois extremos acima nomeados, kratos e ethos. A mecânica do poder, tão genialmente descrita por Maquiavel, transferiu a substância ética do Estado para a familia e a sociedade civil, despojando-a do caráter universal que ela possuía no espaço público. O poder tornou-se uma técni-

\footnotetext{
34 Para uma reflexảo mais aprofundada, consultar Henrique Vaz, Escritos de Filosofia II, Ética e Cultura, Loyola, 1988, capitulo sobre Ética e Politica, p. 257 e seguintes.

15

A Idéia da Razão de Estado na Históna Moderna, traduçáo italiana, L'Idea della Ragion di Stato nella Storia Modema, Vallechi Edit., Florença, 1942, v̀. 1, p. 12.
} 
ca, dotada de um preâmbulo, que ensina como adquiri-lo, e de um manual de manutenção, composto de judiciosos conselhos de como conservá-lo, se necessário com o recurso ao crime e à fraude. $\mathrm{O}$ uso privado do espaço público tornou-se moeda corrente no sistema de trocas que entäo se instalou; e do mesmo modo que a política se apoderou do direito público, o direito privado se viu presa da economia. A substância ética do Estado e do Direito decaiu em mera formalidade; como diz Norberto Bobbio, "como direito privado, o direito tornou-se o momento formal da economia; como direito público, o momento formal da política". ${ }^{16}$

Em toda a parte a instituição do Estado sucumbiu à organização da empresa e governar tornou-se sinônimo de administrar. A era dos gerentes e dos economistas chegou à burocracia estatal. Entre nós, ao dar-se pressa em transferir à esfera privada tudo o que o onera, argüindo, em nome da eficiência, não lhe convir administrar negócios, o Estado brasileiro vem-se desobrigando também, pouco a pouco, de responsabilidades sociais que a Constituição de 1988 havia consagrado. Citemos apenas, para sermos breves, a lenta e cruel destruição da saúde e da educação públicas.

Livrando-se do ônus social, a duvidosa eficiência dos tecnocratas aliou-se à indubitável ineficiência do govemo para finalmente apresentar-nos a conta, instruída a propósito pela contabilidade de lucros e perdas. No momento do acerto, o governo esquece o cidadão e cobra a mais não poder do contribuinte.

Havendo perdido a substância que as nutria, ética e política abandonaram a via comum da razão e seguiram a inspiração que lhes ditava o vulgar entendimento. $\mathrm{O}$ poder procurou em vão legitimar-se pelo sucesso, enquanto a moral viuse reduzida aos limites da vida privada. A censura que por vezes se dirige à improbidade na vida pública é testemunha desta dupla impotência. Se o abuso do poder escapa sempre à condenação e ao desprezo que the vota a moralidade individual, é que esta já não possui a força da vontade social e não é suficiente para coibi-lo. Os bons propósitos se refugiam na vida interior e já não encontram força para afirmar-se como ética universal que une todas as pessoas. Quando o Estado perde a força normativa que o anima, é inútil multiplicar os pactos. Nenhum deles lhe devolverá a soberania se ele próprio não a encontrar em si mesmo.

Em suas conversações com Goethe, Napoleão expressou a opiniảo de que a tragédia antiga se deslocou, no mundo moderno, para o palco da política, vindo a pesar sobre o cidadão como um destino inelutável que nada perdoa, como as antigas Fúrias.

A tragédia clássica representava a liberdade do homem em luta contra um destino misterioso e irrevogável, fruto do arbítrio dos deuses. A vitória da liberdade, que terminava paradoxalmente na aceitação do sofrimento e da morte, significava contudo um triunfo moral, visto que, ao aceitar o destino, o herói trágico elevava-se acima da fatalidade natural e a subordinava à consciência do espíito livre. O homem torna-se superior aos deuses, que não conseguem libertar-se dos caprichos e dos desejos que os assaltam, isentos de qualquer lei. A hybris é a arrogância que não conhece medida. Por isto, no primeiro coro da Antígona, Sófocles celebra o homem livre, chamando-o "mais admirável que todas as coisas admiráveis".

16 BOBBIO, Norberto. Studi hegeliani, Hegel e il Diritto. Turim: Einaudi, 1981, p. 41. 
A tragédia no ético que caracteriza os novos tempos opõe da mesma forma a liberdade ao destino, aqui representado, contudo, pela submissão à causalidade eficiente das necessidades sociais, que escravizam o homem. Delas ele não consegue mercê, a não ser quando, organizadas racionalmente, elas mesmas se submetem ao imperativo do Estado de direito, isto é, ao Estado da Razão e da Liberdade. Deste modo, o sistema das necessidades, no qual vive a sociedade civil, encontraria no Estado as garantias que os egoísmos individuais não saberiam oferecer. A tragédia política vem do fato de o Estado mostrar-se impotente para cumprir sua finalidade. Sempre é preciso, como Hamlet, lutar contra um mar de dificuldades sem que se consiga escapar à ultrajante Fortuna, ${ }^{17}$ pois o Estado tornou-se o lugar do conflito, deixando de ser a instância do direito à qual recorrer para se resguardarem as liberdades. Corromperam-no as conveniências da riqueza.

\section{Epílogo}

Estando a Universidade a celebrar os quinhentos anos do descobrimento do Brasil, é lícito perguntar que tarefas lhe seriam mais pertinentes nesta efeméride. Penso que, fiel à cultura da Razão, que é inseparável de seus misteres quotidianos, a Universidade deve investir-se, com todo o empenho, de uma nova consciência ética, com a qual possamos ingressar no próximo milênio. Examinemos brevemente esta questão.

Tendo considerado o mundo ético como abandonado por Deus, o niilismo da modemidade deixou-o entregue ao arbitrio individual. Sociedade e Estado perderam a universalidade de sentido que os caracterizava e foram obrigados a recorrer à ficção de um pacto capaz de restaurar, ao menos hipoteticamente, o que se chamou de a vontade geral.

$\mathrm{Na}$ indigência de Sentido que caracteriza nossa época, a ética do dever foi arrancada do solo substancial que a nutria e voltou-se para o interior da consciência, de onde contempla indignada, mas ausente, a maldade do mundo. Ela não pode, contudo, permanecer por muito tempo fechada em si, sem contradizer a pulsão infinita que a empurra para fora e a faz descontente com toda satisfação parcial. Só o todo é verdadeiro. A vontade ética é fome e sede de transcendência, de encontrar-se a si mesma em todos os outros. Ela é sempre tempestade e ímpeto que só se acalma no Absoluto. A liberdade é o mundo que o homem acrescentou à natureza para poder existir, por isto ele não pode deixar de construí-lo sem negar-se a si mesmo.

A construção do universo social tornou-se no entanto mais complexa do que o supunha a visão dos dois brasis. O que parecia o dualismo básico de senhores e escravos surge agora como um múltiplo disperso, que ora se reúne em volta de um ponto de tensão, ora se dissolve para se encontrar em outro, em infindável troca de lugar. A multíplicação da diferença torna impossivel aprisionar o mundo ético numa alma comum capaz de expressar a identidade nacional. A ética do

17 Hamlet, Ato III, cena I. É preciso ler toda esta famosa cena para se compreender o intenso sofrimento moral causado pelo destino inerente às relaçōes de poder. 
novo milênio há de ser pluralista se quiser ser justa; seu lema não poderá ser "um povo, um costume", porque a diversidade cultural já não o consente. A identidade deverá expressar, por conseguinte, a "identidade na diferença", mantendo-se fiel respeito às opções de pessoas e grupos. Se não se pode pensar em unificar o comportamento, pode-se no entanto definir um fundo comum de liberdade, onde os direitos e os deveres encontrem reconhecimento. Este é, por excelência, o trabalho da razão. Sendo comum a todos os homens, a razão é capaz de aproximar o que as paixões separam.

Essa ética da diferença deverá avançar até o indivíduo, pois cada indivíduo é o próprio homem. Chegamos, desta sorte, à ética dos direitos humanos e do respeito ao valor universal da pessoa. Deu-se grande passo para seu reconhecimento no momento em que a tortura, a crueldade e a degradação moral foram definidas como crimes contra a humanidade. Falta, por certo, ainda muito para prevalecer urbi et orbi o que se conquistou no conceito. Mas é auspicioso considerar que, por afetar a humanidade inteira, esses crimes podem e devem ser julgados em qualquer lugar do mundo por tribunais competentes, não logrando mais esconder-se atrás das razões de Estado para escapar à punição. Detentora de um valor universal, a pessoa leva consigo o direito para toda a parte.

A legitimidade do discurso ético terá de ser medida por sua ressonância no mundo real, como instrumento de mudança e transformaçăo. A diferença é nossa reflexão em outro, sem destruir o que o outro é; neste sentido, diferença é também transcendência.

Ao completar sua meditação sobre a tragédia na história e na política modernas, Jean-Marie Domenach indica uma dessas necessidades que, simples na aparência, no entanto se põe como um desafio ao mesmo tempo difícil e inadiável:

"O divórcio da cultura e da sociedade é um dos elementos do trágico político numa época em que o poder, tornado democrático, tem necessidade, precisamente, de uma justificação filosófica e de uma expressão ideológica. ${ }^{\text {18 }}$

Depois de encerrado o ciclo dos govemos militares, restaurou-se no Brasil, ao menos formalmente, o Estado de direito. A cultura brasileira chega agora ao momento em que a consciência da liberdade, educada na dor e na separação, coloca o imperativo da justiça. A riqueza e a opulência não podem mais conviver com a privação mais abjeta. Venha-nos, pois, o Estado ético, no qual as liberdades possam encontrar-se, reconciliadas. Possa a justiça assumir o poder da verdadeira Palavra, aquela que decide e institui. Como a corda estendida sobre o abismo da separação, a distância entre os extremos tornou-se demasiado grave para que a possamos suportar por muito tempo.

Ao contrário das viagens de descoberta, o discurso nunca chega a porto seguro onde possa lançar âncora. Sendo infinito o caminho da razão, toda conclusão traz consigo a exigência de novos começos. A dificuldade de dizer nós é maior do que gostariamos de admitir, porque de nada adianta falar sozinho. A possibilidade de dizer nós, brasileiros, só se tomará realidade viva se todos pudermos trocar, em conjunto, as palavras do reconhecimento e da justiça, como se fossem a moeda

1s DOMENACH, Jean-Marie. Le retour du tragique. Paris: Seull, 1967, p. 159. 
espiritual capaz de nos unir. Não poderemos, pois, fazê-lo no isolamento das consciências. Mas se não temos ainda "esperança de porto e salvamento", podemos no entanto exortar à tarefa comum, que é a mais perigosa e ao mesmo tempo a mais urgente: Refaçam-se os caminhos da Independência! Restaure-se a Soberania do Estado!

Os navegantes que aqui aportaram há quinhentos anos sonhavam com a visão do paraíso, posto no passado mítico pelo Criador. Perdemos hoje a ilusão de encontrar algo maravilhoso, esteja onde estiver. Afinal, a utopia não está em lugar nenhum. A indigência dos tempos já nos proíbe crer em qualquer coisa que nós mesmos não tenhamos feito. A realidade de nossa vida está sempre por fazer, e o espírito do povo, dilacerado pelo absoluto desamparo, busca em si mesmo a força de um novo começo. Esperança é o outro nome da utopia. Dar-lhe realidade é tarefa que incumbe a todos nós. Ao assumi-la, tenhamos no ânimo o que as palavras da independência ensinam:

Longe vá temor servil. 